\title{
A CASE OF NON-HEALING GRANULOMA OF THE NOSE WITH SMALL INTESTINAL INVOLVEMENT (MALIGNANT RETICULOSIS)
}

\author{
YASUO WATANABE, M.D. \\ ENT-clinic of Osaka Prefectural Hospital \\ HITOSHI OGINO, M.D. \\ ENT-clinic of Toyonaka Municipal Hospital \\ SHUNICHI SAKAI, M.D. \\ ENT-Clinic of Osaka Kaisei Hospital \\ MASANAO OKADA, M.D., AND MASAMITSU TAMAI, M.D. \\ The 2nd Dept. of Pathology, Osaka University School of Medicine
}

An autopsy case of malignant granuloma of the nose with intestinal involvement was presented.

A male, aged 24, who developed rightnasal obstruction and bleeding, visited us on April 10, 1974. On examination, necrotic granulom atous changes of the right turbinate were found.

Repeatd biopsies of the nasal lesion, however, showed only inflammatory changes and necrosis. He did not respond to antibiotics and corticosteroid therapy, and malignant lymphoma of the nose was suspected. A satisfactory response was obtained by radiation therapy. Four months later, he had pain of the right eye and exophthalmus. Biopsy of the nasal lesion revealed infiltration of atypical histiocytes.

Inspite of irradiation, antibiotics and corticosteroid therapy, he complained of severe pain in the orbit and over the abdomen.

Laparotomy revealed many necrotic lesions of small intestine with a perforation, and microscopic examination of the lesion showed diffuse infiltration of atypical histiocytes into the muscle of small intestine, and also atrophy of the muscle.

He died of bleeding from the small intestine after 6 montls from the oncet. Autopsy disclosed diffuse infiltration of atypical histiocytes into many organs, stomach, duodenum, small intestine, pancreas, kidney et al.

Based on the experiences of the similar 10 cases, the following points were stressed.

1) In the non-healing granuloma of the nose, there are at least 2 different diseases, one reticulum cell sarcoma or malignant reticulosis, another Wegener's granulomatosis.

Initial changes of the diseases are similar and biopsies of the lesions show only the same inflammatory changes and necrosis.

2) One must consider malignant reticulosis rather than Wegener's granulomatosis in case show. ing no characterisic laboratory findings of Wegener's granulomatosis........elevated BSR, Positive RA, decreased A/G ratio, elevated Ig, IgG, IgA and serum complement level.

3) When a patient with no definite histopathological features and laboratory findings develops abdominal pain, intermittent fever, jaundice or dyspnea in times, the infiltration of atypical histiocytes to the intestine, kidney, lung or pericardium should be suspected. 
A $81-0789-32301$

\title{
小腸に穿孔をきたした鼻悪性細網症の 1 例
}

\author{
大阪府立病院耳鼻咽喉科 \\ 渡 部 泰 夫 \\ 豊中市民病院耳鼻咽喉科 \\ 荻 野仁 \\ 大阪回生病院耳鼻咽喉科 \\ 酒 井俊 一 \\ 大阪大学医学部第二病理学教室 \\ 岡田正直，玉井正光
}

\section{I はじめに}

鼻を中心に壊死性肉芽性病変をきたすいわゆる進行性 鼻壊疸あるいは壊疸性鼻炎といわれる疾患にはいるいる の病態が含まれている(122334)576)7781.

その中でも Wegener 肉芽腫と鼻細網肉腫あるい法鼻 悪性細網症は治療方針をたてる上で早期に鑑別されるべ き病態であるが初期の組織診では区分し難い場合が少な 〈ない,9)10>11〉

これら $2 つ 0$ 疾患汸病期が進んだ段階では特徵的な 全身性の病態を示す，とくに鼻悪性細網症は細網采の 細胞の浸潤が全身におよびその予後は極めて不良であ $ろ^{1213)(4)}$

鼻症状を初発症状とし急激な経過で多発性の小腸穿孔 をきたした細網症の1例を報告し今日をでの自験例を参 考に進行性鼻塄疸に含まれる悪性細網症の初期病变と浸 潤の特徴,および治療について検討した。

\section{II 症 例 報告}

·患 者 24 才の男子.

職業：自動車工（その前にエノキダケの栽培 に関与していた）

・初診日 昭和 49 年 4 月 10 日

・主 訴 鼻閉, 鼻出血

・家族歷 特記す心゙きことなし

・既往歷$$
\text { " }
$$

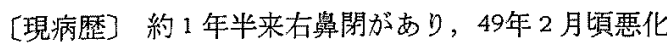
し，一時眼窩下部がはれ，頭重感も起った。 4 月頃より 鼻閉のため不眠状態になる。鼻汁は粘液性で血性ではな かったが，1 週間前より近医で洗浄後出血をきたすよう になった。
[来院時耳鼻科所見]

\section{前鼻鏡所見}

右側の中甲介と䩿中隔が一部壊死性肉芽性变化を示 し，右下甲介にやや腫瘤状で一部に潰瘍性病変を認め た.

左側の鼻腔所見はほぼ正常.

口蓋, 咽頭, 侯頭上もに異常なく, 頸部リンパ節も触 知しない。

\section{[検查成績]}

- 鼻部生検像：壊死上炎症性肉芽組緎，一部に血管周囲 炎を認める(写真 $1 ， 2)$.

·血液検查

検血 赤血球 $502 \times 10^{4} / \mathrm{mm}^{3}$

$\mathrm{Hb} \quad 13.6 \mathrm{gr} / \mathrm{dl}$

$\mathrm{Ht} \quad 42 \%$

白血球 $6500 / \mathrm{mm}^{3}\left\{\begin{array}{l}\mathrm{N}-78 \\ \mathrm{E}-0 \\ \mathrm{~B}-0 \\ \mathrm{~L}-20 \\ \mathrm{M}-2\end{array}\right.$

赤沈值 $\quad 9\left(1^{\circ}\right)$

血清 CRP (-)

RA (-)

ASLO 100 T.u. 以下

血清蛋白 T.P : 7.5, Al : 60.8

$\alpha_{1}:: 2.2, \alpha_{2}: 9.9$

$\beta: 9.1, \gamma: 17.6$

検尿 糖(一) 蛋白(一)

副鼻腔X線所見

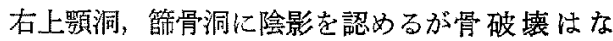




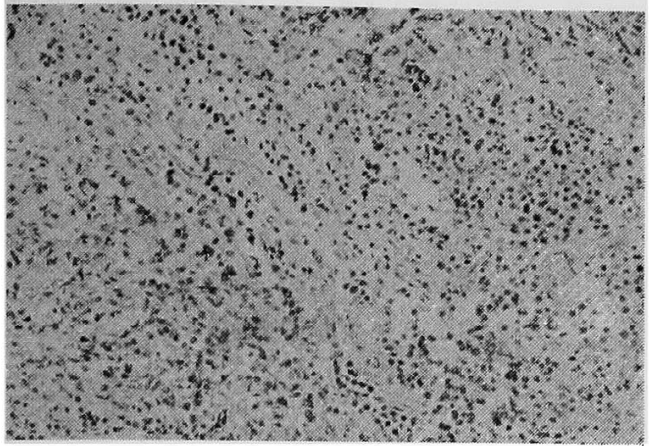

写真 1 鼻の生検 (1) (49.4) ×100

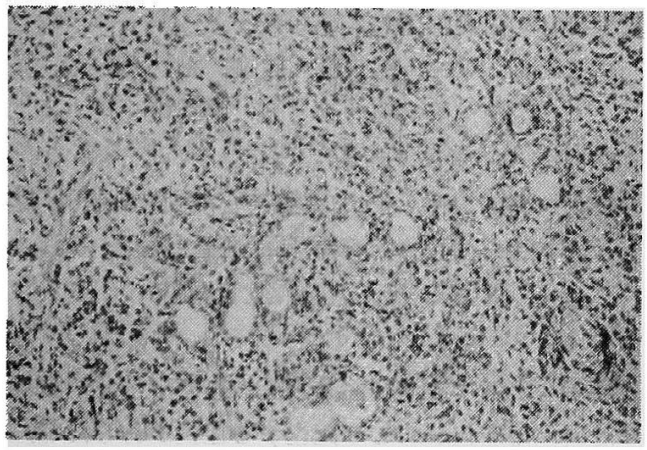

写真 2 鼻の生検(2)(49.4) × 100

w

嗅覚検査 (10種)

右側 (一)

左側やや低下

[経過]

49年 4 月10日より副腎皮質ホルモン剂投与（リンデロ ン $2 \mathrm{mg}$ /日より漸減）したが余り効果なかった，生検で 細網肉腫と決められなかったが進行性鼻壊疸の中どちら かというとWegener 肉芽腫より細網肉腫に近いと考 え, 副腎皮質ホルモン郕, 抗癌剤, Lineac X線照射 (4 月24日より5月31日まで 4000rads）の治療をした。その 後一時症状消失し薬物投与も止め経過観察したところ 7 月23日右眼瞼腫脹, 右眼球突出, 右眼痛, 右頭痛をきた した(写真 3 ). リンデロン $2 \mathrm{mg} /$ 日に増量, 8 月 1 日一 度退院するが眼痛再燃した。リンデロンの増量 ( $3 \mathrm{mg} /$ 日）の効果少なく 8 月 10 日再入院した.この間 8 月 3 日 の組織再検で悪性リンパ腫と診断された(写真 4 ).

8 月20日頃より眼痛激しくなり, Lineac X線照射再開 するが (3000 rads) 9月になり腹痛, 嘔吐つづいて下血

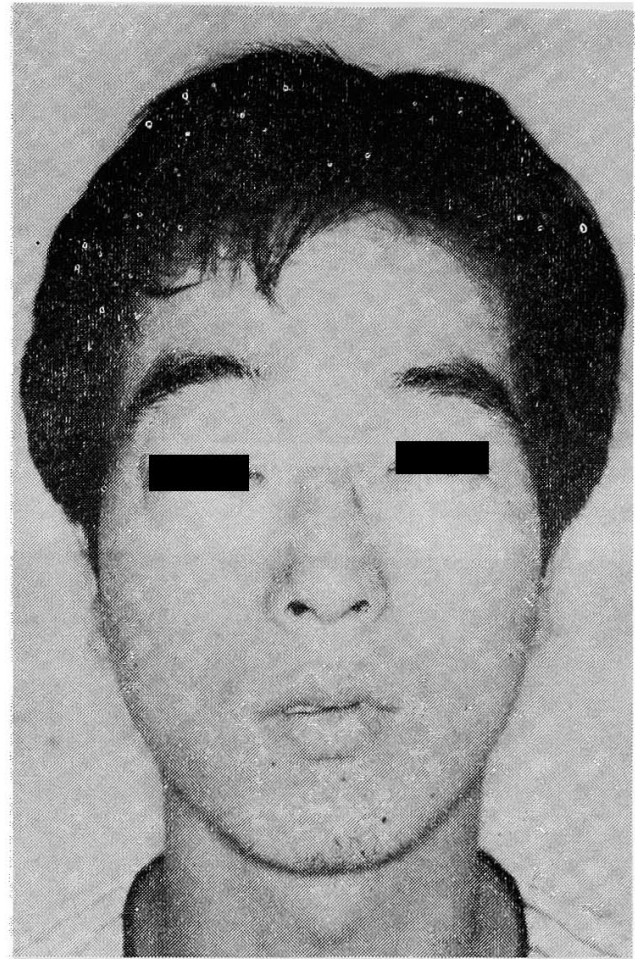

写真 3 右眼球突出 (49.8.16)

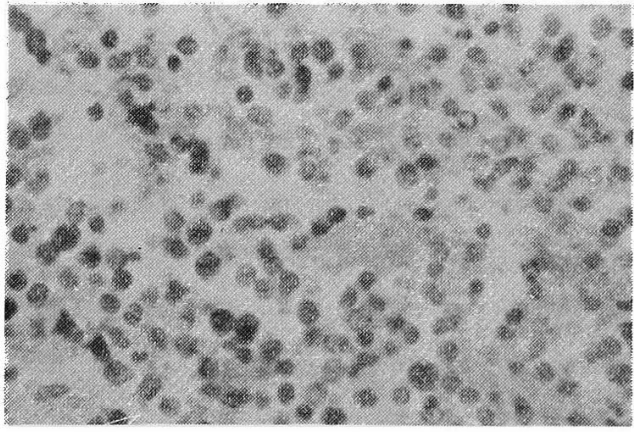

写真 4 鼻の生検 $(49.8) \times 400$

が出現し穿孔性腹膜炎を疑い緊急開腹術を依頼した。手 術時小腸の 7 力所に穿孔前段階の潰瘍性病変および 1 力 所に穿孔を認めた(写真 5 ). 穿孔部切除, 縫合が行われ たが術後なお下血が続き 10 月 11 日多量の吐血をきたし死 亡した。

[病理解剖所見] 阪大第二病理

（主病変）(1)悪性細網症

浸潤部位 広範びまし性 


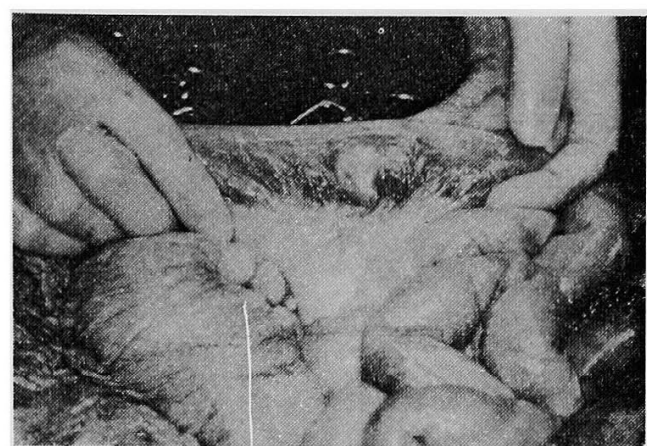

写真 5 小腸の穿孔（開腹手術時）

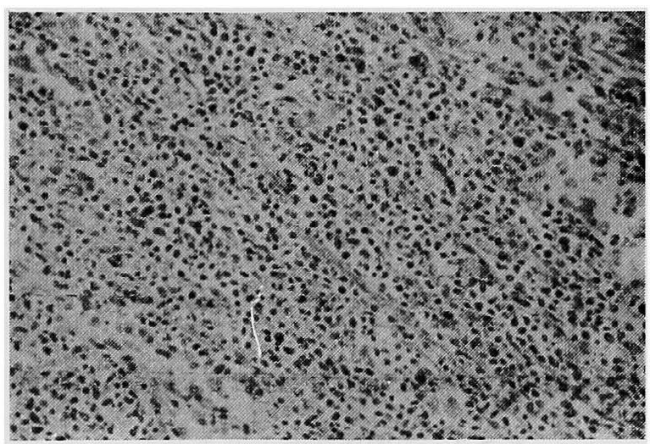

写真 6 胃 (剖検) $\times 100$

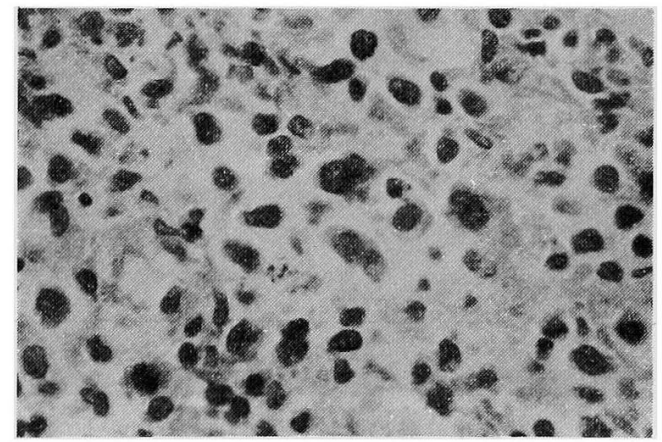

写真 7 胃 (剖検) $\times 400$

(2)穿孔性腹膜炎……11による消化管潰瘍の穿 孔を原因とする。

(副病変) 肺 $う っ$ 血, 胸水, 膵脂肪壊死, 精巣萎縮, 副 脾, 大動脈アテローム変性軽度

形態学的に悪性と思える細胞が,びまん性に白血病様 浸潤を示寸点より“悪性細網症”と診断した。

浸潤の主座は胃，小腸にあった(写真 6， 7，8).

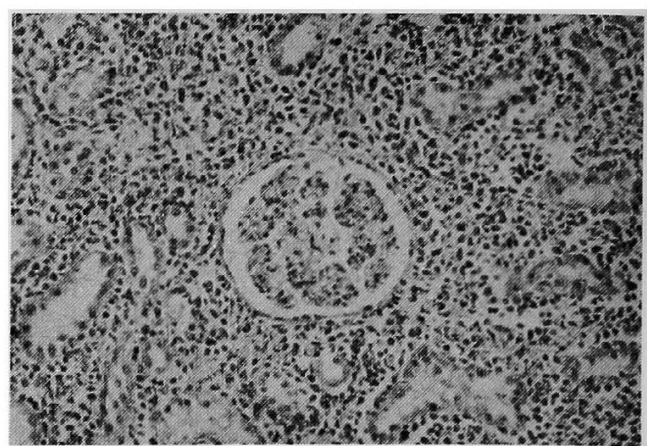

写真 8 腎(剖検)

異型細胞の浸潤程度および局在

高度: 胃, 十二指腸, 膵, 腹膜, 心, 大動脈, 腎, 胸腺，傍気管リンパ節，腸間膜リンパ節

中等度 : 胆のう, 結腸, 下垂体

軽度 痕跡：脾, 肺, 大脳中心前回 (軟膜), 視床 (血管周囲)，海馬傍回(血管周囲), 中脳（血 管周囲)，橋，小脳 (血管周囲)

\section{III 考察}

従来よりいわゆる進行性鼻壤疸の経過中に急性腹症の ような消化器症状がおこり死亡する症例があったが，そ の原因，本態に関しては余り注目されていなかった。

進行性鼻壞㾝には本態が明らかでない複数の疾患が含 まれているが初期の局所病変による爁別診断が難しいた め全身性の病変をきたした場合，局所病変がどのように 進展したのかあるいは，別の病態がおこったのか把握し 難い場合も少なくない．

本症例は死亡前に開腹術により小腸に多数の穿孔前段 階の潰瘍性病変を認め組織検查で細網系細胞の浸潤によ る筋層の萎縮が認められた。

進行性鼻壊㾝の中には本症例のように初期の組織診で は判断できないが経過とともに細網細胞の浸潤が全身に みられる悪性肉芽腫がある15)

本症例を含めこのような場合の初期病変である鼻の肉 芽の組織診は極めて難しい 本症例の初診時の組織診も 単なる炎症と血管周囲炎であり局所生検で悪性リンパ腫 の診断ができたのは 4 力月後であった。

進行性鼻壊㾘の初期の鼻部の肉芽の組織診は多くの場 合, 炎症あるいは炎症性肉芽で時に大型の組織球が散在 性に認められることもあるがこれらは腫瘍細胞というよ り反応性のものと考えられやすい

このようなことは石井 ${ }^{16)}$ の述べるごとく本疾患の異型 
細胞の origin に関係しているかと思われる，鼻は本来 リンパ組織が少なくリンパ腫啺の頻度は扁桃などに比し 少ない，

局所リンパ節が触知されないことや転移も結節を形成 しないで浸潤といら形式をとることもこのような origin に関係した結果と考えられている.

腫瘍性の性格が隠されていることと臨床像が Wegener 肉芽腫の初期と似ているた的鑑別を難しくし，したがっ て治療方針の決定が遅れる原因となっている。

この両者の鑑別は組織診のみでは不充分で他の検查成 績も参考にする必要がある。しかし本来，細網症には特 徽的な検查所見は少なく本症例でも末期の $7 \sim 8$ 月に末 梢白血球分類で単球が増加した位でむしろ次のような 異常検查成績がみられたときは Wegener 肉芽腫の疑い が強く，逆の場合は細網症が疑われる。

Wegener 肉芽腫型にみられる異常検查成續は 赤沈值 の穴進が著しいこと苚118)， CRP， RA の陽性， $\mathrm{A} / \mathrm{G}$ 比 の逆転, $\alpha_{2}$-globulin, Ig の増加, IgG, IgA の増加 ${ }^{17220)}$, 血漿フィブリノーゲン值の六進, ッ反応の陰性化 ${ }^{17) 18}$, 血清補体価 $\left(\mathrm{CH}_{50}\right)$ の六進 ${ }^{21) 22}, \mathrm{ChE}$ の低下，好中球

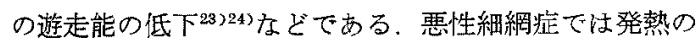
割にこれらの変化は少ない

臨㦿所見の特徵としては悪性細網症の初期病変は本症 例のごとく一側の壊死性病変がつよいことが多い25) た だし一見健常な鼻中隔を介して両側に同時にみられる場 合や，一側でも中甲介と下甲介に病変がある局所多発的 な初期像のここもある。，一方 Wegener 肉芽腫は両鼻腔 の境である鼻中隔が犯されることが多い（約80\%の症例 にみられる).

組織検查法では両者とも壤死と炎症像がつよいが Wegener 肉芽腫の場合巨細胞がみられることが特徴で 西る。また血管炎は両者にみられるが，フィブリノイド 変性をともなった血管资は Wegener 肉芽腫にみられ $3^{28) 27)}$

本症例の剖検では肉眼的に全身性の腫瘤結節を認めら れず全身リンパ節缠大は軽度で消化管の多発性潰瑒およ びその穿孔が認められた．顕微鏡的には核は類円形で一 部分莱化あるい性多核のものもあり，クロマチンに富み 原形質に乏しい悪性と思われる細胞が胃，十二指腸，空 腸の潰演部は勿論, 他の部位にもびまん性に浸潤を示し 筋層の萎縮，消失などをきたしていた．

この異型細胞は消化器以外に，心，腎，胸腺などにも 白血病様に浸潤增殖していた。剖検時のこれらの所見よ
り本症例は埥性細網症と考えら九た。

本症は既述のごとく初期の上気道の病変よりの診断が 困難であること，頸部，頡下リンパ節などのリンパ節の 腫脹にかけることも特徴である上，本症が予測されて も，ガリウムシンチグラムなど行っても末期まで全身性 の異常所見はつかめない

これは本症例にみられるごとく小腸, 肝, 心, 腎など への浸潤がいずれも散在性であり結節を形成しない結果 と思われる。

全身性の浸潤が検査法として証明できないため臨床症 状である高熱，小腸穿孔による腹痛，肝一の浸潤による 黄㾞，あるいは心浸潤による心不全，肺への浸潤に よる呼吸困難など他の合併症も薬物の副作用などと考え られやすい 異常検査所見の少ない本疾患の診断は組織 診あるいは細胞診を繰り返し試みる以外に今のところ決 め手はない 決め手のない段階ではある程度臨床家の経 験によらざるを得ないと思う。

本症と同しような症例を十数例経験しその中10例の死 亡例（本症例を含め）の経䢔年月と初発症状を比較のた め表 1 に示寸，年令注18才から62才(平均38才), 男：女 $8: 2$, 初診より死亡までの期間は 6 力月以内が 7 例, 前駆期は 2 力月 3 年, 初発症状上り死亡までは 4 力月 $\sim 5$ 年 5 力月 (平均 1 年 10 力月) である,

本症の治療にはいろいるの問題がある，最後の剖検所 見あるいは末期の生検所見よりするとやはり悪性リンパ 腫の治療に準じて行うべきであるが，初期の組織診で既 述の如く悪性リンパ腫といら決めてを欠くことが多いた め, 初期の治療で筧解した場合は維持療法, 強化療法 （初回に用いたと同じ位の大量の化学療法郕を用いる） を徹底的に（骨䯣への影響が可逆的である限界まで）行 なうことに訾踷し勝ちになる。どうしても少し不徹底に なり勝ちである。

少数ながらにが、経験の上に立つと，鼻腔にみられる 進行性壊死性肉芽性病変で組織診, 血清化学, 細菌検查 などの検査で実態が判った場合を除けば悪性細網症の初 期所見であることを教えて放射線療法, あるい柱化学療 法を長期にわたり行らべきと思う。

今ひとつの問題任ほとんど現在の化学療法剂に反応し ない場合であるが，この場合を考えれば極く早期に外科 的方法を行ら方がよいのではないかという点である。

全身性の細網系の変化の初期変化が鼻で早くみられた のであれば，外科的漅法は無意味であるが鼻部の細網系 細胞の浸潤が転移あるい汒他の臟器に影響したと考えれ 
表 1

\begin{tabular}{|c|c|c|c|c|c|c|c|c|c|c|}
\hline 症例 & 氏 名 & 年齢 & - 性 & \begin{tabular}{|c|} 
前駆期 \\
(初診まで)
\end{tabular} & 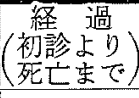 & 全経過 & 主 訴 & $\begin{array}{l}\text { 経過中の炎 } \\
\text { 症像, 発熱 }\end{array}$ & $\begin{array}{l}\text { 浸潤 } \\
\text { 病変部位 }\end{array}$ & 尿蛋白 \\
\hline 1 & H. $\stackrel{*}{\text { T. }}$. & 24 & $\hat{o}$ & 1 年半 & 6 力月 & 約 2 年 & 右鼻閉 & 発熱 (+) & 胃・腸(他) & $(-)$ \\
\hline 2 & S.S. & 24 & $\hat{o}$ & 7 力月 & 5 力月 & I年 & 右鼻漏 & 発熱 (t) & 腸管( ?) & $(-)$ \\
\hline 3 & H. A. & 50 & q & $\begin{array}{c}\text { 若、頃よ } \\
\text { 鼻漏 } \\
\text { 3力月 }\end{array}$ & 5 力月 & 8 力月 & $\begin{array}{l}\text { 右齅根部 } \\
\text { 脤 }\end{array}$ & 末期発熱(十) & 肝・脾(他) & $(-)$ \\
\hline 4 & H. N. & 44 & $\hat{\delta}$ & $\mid \begin{array}{c}\text { 小监期より } \\
\text { 鼻がわる心 } \\
2 \text { 力 }\end{array}$ & 3 力月 & 5 力月 & 鼻汁 & 発熱 (t) & 肝・脾(他) & $(-)$ \\
\hline 5 & Y.S. & 52 & $\hat{o}$ & \begin{tabular}{|c|} 
数年来鼻閉 \\
$2 \mathrm{n}$
\end{tabular} & 力月 & 5 年 5 力月 & $\begin{array}{c}\text { 左鼻閉 } \\
\text { 左鼻の有 } \\
\text { 痛性腫脹 }\end{array}$ & 発熱 (t) & 肺( ? ) & $(-)$ \\
\hline 6 & $\mathrm{~T} . \stackrel{* *}{\mathrm{~S}}$. & 18 & $\hat{o}$ & 2 力月 & 2 年 & 2 年 2 力月 & $\begin{array}{l}\text { 左鼻漏 } \\
\text { 閉 }\end{array}$ & 発熱（+） & 腸管（？） & $(-)$ \\
\hline 7 & $\mathrm{H} . \mathrm{F}$. & 23 & q & 1 年半 & 5 力月 & 約 2 年 & $\begin{array}{c}\text { 齅出開 } \\
\text { 血 }\end{array}$ & 発熱（+） & 心(?) & $(-)$ \\
\hline 8 & $\mathrm{~K} \cdot \mathrm{N}^{*}$ & 45 & $\hat{o}$ & 2 力月 & 2 力月 & 4 力月 & $\mid \begin{array}{c}\text { 鼻閶 } \\
\text { 部腫脹 }\end{array}$ & 発熱（十) & $\begin{array}{c}\text { 肺 ·肝 · 脾 } \\
\text { (他) }\end{array}$ & $(-)$ \\
\hline 9 & E. T. & 62 & $\hat{o}$ & 3 年 & 2 力月 & 3 年 2 力月 & 右鼻閉 & 発熱 (+) & 腸管( ?) & $(-)$ \\
\hline 10 & $\mathrm{Y} . \stackrel{* *}{\mathrm{~K}}$. & 22 & $\hat{o}$ & 2 力月 & 11力月 & 1 年 1 力月 & 右鼻閉 & 末期発熱 (十) & 腸管( ?) & $(-)$ \\
\hline
\end{tabular}

*剖検

**他病院で死亡

ば初期の段階での広範な切除は意味があると思われる。 私の場合, 組織の切除を行ったのは No. 5 の症例だけで あるが（この症例は組織診が不確実であったので組織像 の確認をかね大き(切除した）この症例は偶然か 5 年 5 力月と経過が死亡症例の中では最も長かった（現在蔡物 治療，放射線治療で 5 年を経過して健在な症例をもって いるがリ。

他の悪性疾患と同様，本疾患む原因不明でありさらに その病態の不可解なところより，治療方針を決める際に 一定の方針が確立されていない現状は患者にとり不幸な ことであると言わざるを得ない

今後本症の遠隔成績の集計を行らことにより経験的に 最良の方針を挆ることがと沈く必要と考える。

診断上の問題としては現在の組織, 細胞形態学的手段 には限界があると思わざるを得ない。

T-cell, B-cell などがリンパ球の membrane marker の特徴で区分され，免瘦学的にリンパ腫瘍の分類が行わ れてきたことは(28)29/30/31332)33334)本疾患の診断にも役立ら
そうで，今後新しい手技の開発を期待したい。

一方 Wegener 肉芽腫の方の初期診断の進歩 (形態学 的より血清化学あるい注炎症誘発因子の解明）も鑑別に 役立つことと思う。

$\mathrm{IV}$ ま と

(i) 初期の局所の組織生検で進行性鼻壊瘟と考えられ た 1 症例が 6 力月の経過で小腸の多発性穿孔による出血 をきたし死亡した1例を報告した，患者沬24才の男子で 主訴は鼻閉上鼻出血であり，初期の組織生検で注炎症性 肉芽であったが末期の鼾組織生検像上小腸の穿孔部の組 織像より悪性細網症と考えられた。

(ii) 過去の自験死亡例10例を亡と的本症と同棣な経過 を示す症例の少なくないことを報告するとともに，次の 点を強調した。

1. 進行性鼻壊疸に含忠れるいくつかの疾患の中, 全 身性病変を示寸 Wegener 肉芽腫と悪性細網症の初期病 変は似ておる生険像も鑑別し難い場合が少なくない，

2. 現段階では Wegener 肉芽嗹としての特徴（赤沈 
値の六進， Ig の増加，尿所見，組織診での巨細胞の出現 など）に欠ける場合，悪性細網症と考え強力に，加長 期に徹底的に加療する必要がある。

\section{参考文献}

1) Stewart JP: Progressive lethal granulomatous lesion of the nose. J. Laryng 48:657-701, 1933.

2) Walton EW: Giant cell granuloma of the respiratory tract (Wegener's granulomatosis). Brit. Med. Journal 2 : 265, 5087-5099, 1958.

3) Walton EW: Non-healing-granuloma of the nose. J. Laryng $73: 242-260,1959$.

4) Walton EW: Reticulo-endothelial sarcoma arising in the nose and palate (grangrenescens). J. Clini. Path 13:279-286, 1960.

5) 渡部泰夫，他：死の転帰をとった鼻悪性肉芽腫 4 例 日耳鰠 $79: 36-49,1976$.

6）北村 武，他：壊疽性鼻炎の診断 日耳鼻 72 ： 2081-2088, 1969

7）切替一郎：いわゆる壊㾇性鼻炎の本熊 耳喉 42 : 783-791, 1970.

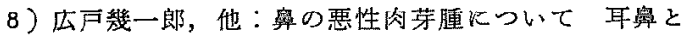
臨床 $19: 349-360,1973$.

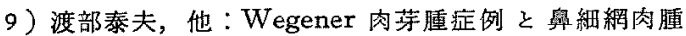
症例 日耳鼻 $74: 105-113,1971$

10）形浦昭克，他：Wegener 肉芽厘症例々鼻細網肉腫 症例 耳鼻臨床 $68: 299-306,1975$.

11）渡部泰夫：進行性鼻罗誼の組織誩 耳喉 48：635$643,1976$.

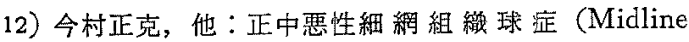
Malignant Reticulohistiocytosis)一いわ注推徃 鼻壊痺 癌の臨床 20：684-691，1974.

13）渡部泰夫，他：番細網肉堙症例 日耳鼻 $76: 25-$ 36,1973

14）渡部泰夫：鼻恵性勫網症 耳㬋 49：706-707, 1977.

15) Fecher RE, et al.: Midline 'Malignant Reticulosis. Arch Otolaryng 95:467-476, 1972.

16）石井善一郎，他：鼻細絧肉腫の病理学的特異性なら びにその開悪性肉芽腫との接点にっいて耳鼻

18:151-154, 1972.

17）渡部泰夫：Wegener 肉芽腫とその類似鲎疾患耳 舅 $18: 170-175,1972$.

18) Watanabe $Y$ : Classification and laboratory reports on non-healing granuloma of the nose.
The proceedings of the second Asia-Oceania Congress of Otorhinolaryngology 566-573, 1971.

19）石川嘹，他：Wegener 肉芽腫症およびその類似

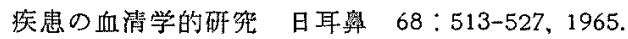

20) Shillitoe EJ, et al.: Immunological features of Wegener's granulomatosis. Lancet, February 23 : 281-284, 1974.

21）渡部泰夫，他：Wegener 肉芽腫とその類似舀疾患 に括沾る血清補体洒 耳㬋 $47 ： 49-55,1975$.

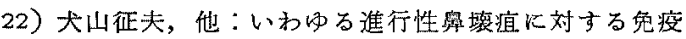
学的检討 耳喉 49:501-508, 1977.

23) Niinaka $T$, Watanabe $Y$, et al.: Chemotactic defect in Wegener's granulomatosis. Journal of Medicine 8:161-175, 1977.

24）渡部泰夫, 他：Wegener 肉芽嗹の病因 - 病態飞関 する研究 (I)一好中球の chemotaxis にっいて一 耳雉 50 : 197-203，1978.

25) Eichel BS, et al.: Primary lymphoma of the nose including a relationship to lethal midline granuloma. Am. J. of Surgery 112:597-605, 1966.

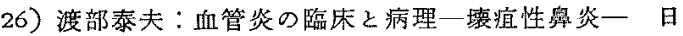
本臨床 $36: 4,87-931978$.

27）渡部泰夫：血管炎をめぐってーWegener's granulomatosis一耳舅科の立場上り 臨床医 4:8, 1978. (投稿中)

28) Lukes $R J$, et al.. Immunologic characterization of human malignant lymphoma. Cancer 34 : 1488-1503, 1974.

29) Lukes $R J$ : New approaches to the classification of the lymphoma. Br. J. Cancer 31 : Suppl. II, 1-28, 1975.

30) Lukes $R J$, et al.: Immunoblastic lymphoadenopathy New Engl J Med 292: 1-8, 1975.

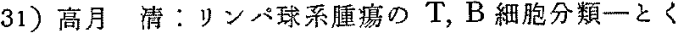
飞成人の T勫胞白血病 日本臨床 $34: 5,886-899$, 1976.

32）菊地幸吉，他：T cell, B cell 白血病細胞の surface marker そリンパ增殖性缠演の分類 日本臨床 $34: 900-911,1976$.

33）砂金秀充，他：鼻細網肉腫の免疫学的考察一T cell lymphoma の一症例 耳㬋 49:889-898, 1977.

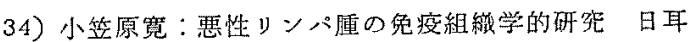


鋲 $80: 1462-1474,1977$.

本論文の要旨は第14回日本部副鼾腔学会（1975年，守 口田), 和上び第15回日本絧内系学会 (1975年, 束京都) に战いて発表した。

開腹手術で御協力媔いた，大阪大学第 1 外科佐谷稳 博士に厭く御礼申し上げます。
（原稿受付 昭和53.3.24日)

別刷請求先 开558 大阪市住吉区万代東4-25

大阪府立病院 耳番咽喉科 渡部泰夫 